\title{
ÉVOLUTION DU SYSTÈME ENZYMATIQUE DU PANCRÉAS ET de L'INTESTIN GHEZ LE PORCELET ALLAité
}

\author{
T. CORRING et A. AUMAITRE \\ Station de Recherches sur l'Élevage des Porcs, \\ Centre national de Recherches zootechniques, I. N.R. A., \\ 78 - Jouy-en-Josas
}

La variation de la composition des aliments du porcelet pendant l'allaitement et le sevrage est bien connue : le jeune animal passe au cours des deux premiers mois de sa vie, d'un régime riche en lipides à un régime riche en amidon, et les répercussions sur son tube digestif sont nombreuses mais encore mal connues (AUMAITRE, I969).

L'animal subit des transformations d'ordre anatomique que nous avons caractérisées par une mesure hebdomadaire (abattage). On peut souligner le développement très important de l'intestin au cours de cette période (allométrie positive) : ainsi. le poids relatif de l'intestin grêle passe de $9 \mathrm{~g} / \mathrm{kg}$ de poids vif à la naissance à $3^{8} \mathrm{~g} / \mathrm{kg}$ à 9 semaines. Le foie présente, par contre, une légère allométrie négative $(29 \mathrm{~g} / \mathrm{kg}$ à $26 \mathrm{~g} / \mathrm{kg}$ ) pendant le même temps, alors que l'estomac présente une isométrie. Mais les transformations les plus spectaculaires sont relatives aux enzymes du pancréas et de l'intestin.

Nous avons ainsi caractérisé le développement de quelques enzymes par un dosage toutes les semaines (naissance à 9 semaines) sur Io animaux à chaque stade : amylase, lipase, trypsine et chymotrypsine du pancréas ; lactase, invertase et maltase dans les trois parties classiques de l'intestin grêle (duodénum, jéjunum, iléon).

L'expression des principaux résultats concernant les activités enzymatiques totales a été retenue. D'une façon générale, on constate une augmentation de l'activité en fonction de l'âge de toutes les enzymes pancréatiques considérées. On peut souligner la faiblesse de l'activité amylolytique du pancréas jusqu'à 4 semaines d'âge où elle atteint $9 \cdot$ Io $^{4}$ unités, puis elle augmente rapidement jusqu'à 8 semaines (35. 10 ${ }^{4}$ unités). On peut conclure à un phénomène d'adaptation de l'amylase à une ration de plus en plus riche en amidon. L'évolution de l'activité lipasique augmente également avec l'âge alors que le régime de l'animal s'appauvrit en lipides. Ce résultat confirme les nombreuses données de Desnuelle et al. (1960-1965) qui n'ont jamais trouvé une adaptation de cette enzyme à la composition du régime. De plus, l'activité de la trypsine à tous les stades est faible par rapport à l'activité de la chymotrypsine. En effet, à tous les stades considérés on peut estimer que le rapport $\frac{\text { chymotrypsine }}{\text { trypsine }}$ est constant et voisin de 4 . Ceci constitue un résultat original, de même quele développement quasi parallèle de la trypsine et de l'amylase en fonction de l'âge.

En ce qui concerne les activités des glucosidases intestinales, on peut souligner la faiblesse des activités enzymatiques au niveau du duodénum. On constate (comme dans le cas du pancréas) une augmentation des activités totales en fonction de l'âge dans les deux segments postérieurs de l'intestin, surtout pour la maltase et l'invertase. Ainsi par exemple, l'activité de la maltase, très faible à la naissance ( $\mathrm{I} \cdot 1 \mathrm{I}^{4}$ Unités Internationales), atteint $\mathrm{I}_{5} \cdot \mathrm{IO}^{4} \mathrm{UI}$ à 3 semaines et $5^{\circ} \cdot \mathrm{IO}^{4} \mathrm{UI}$ à la $8^{\mathrm{e}}$ semaine dans le jéjunum. Les quantités totales d'invertase présentent une évolution comparable mais l'activité à la naissance est nulle dans tous les segments considérés; elle atteint to ${ }^{3}$ UI 
à I semaine et $10 \cdot 10^{3}$ UI à 8 semaines au niveau du jéjunum et une valeur comparable au niveau de l'iléon. Ce résultat est classique et permet de conclure à une adaptation comparable à celle qui est observée pour l'amylase pancréatique. Par contre, en ce qui concerne la localisation des enzymes, nos résultats se différencient de ceux de DAHLQUIST (I96I) qui avait travaillé sur un nombre trop limité d'animaux.

La lactase présente une évolution particulière : en effet, on constate que l'activité de la galactosidase est forte à la naissance dans le jéjunum ( $\left.3 \cdot 10^{5} \mathrm{UI}\right)$, mais on observe une activité maximum vers 6 semaines ( $\left.15 \cdot 10^{5} \mathrm{UI}\right)$, l'activité est plus faible dans l'iléon ( 2 ày $\left.\cdot 10^{5} \mathrm{UI}\right)$ et sensiblement constante avec l'âge ; elle est par contre, à peu près nulle au niveau duodénal. Les valeurs divergent en général des données classiques qui considèrent toujours à peu près exclusivement les dosages de l'activité enzymatique du seul mucus intestinal.

L'ensemble de nos résultats permet de préciser les principaux phénomènes de développement du porcelet pendant la période d'allaitement et de sevrage. On peut considérer que que cette période est caractérisée par le développement de deux organes digestifs, le pancréas et l'intestin sur le plan anatomique (pondéral) mais également sur le plan enzymatique.

\section{SUMMARY}

\section{DEVELOPMENT OF THE ENZYME SYSTEM OF THE PANCREAS AND THE INTESTINE IN SUCKLING PIGS}

It is well known that the composition of the feed of piglets varies during suckling and weaning. The young animal changes from a diet rich in lipids to one rich in starch during the first two months of its life with numerous consequent effects, which are still not well known, on its digestive tract (AUMAItre, I969).

Anatomical changes occuring in the animals were characterized after measurements taken at slaughter at weekly intervals. The considerable development of the intestine during this period must be emphasized (positive allometry) : the relative weight of the small intestine changes according to live weight from $9 \mathrm{~g} / \mathrm{kg}$ at birth to $38 \mathrm{~g} / \mathrm{kg}$ at 9 weeks. The liver, on the contrary, shows a negative allometry $(29 \mathrm{~g} / \mathrm{kg}$ to $26 \mathrm{~g} / \mathrm{kg}$ ) during the same period, while the stomach shows an isometry. But the enzymes of the pancreas and intestine show the most spectacular transformations.

The development of some enzymes has therefore been followed by determining these each week (from birth to 9 weeks) in ro animals : amylase, lipase, trypsin and chymotrypsin in the pancreas ; lactase, invertase and maltase in the 3 parts of the small intestine (duodenum, jejunun, ileum).

The principal results concerning the total enzymatic activities may be expressed as follows. As a general rule, there is an increase with age in the activity of the pancreatic enzymes studied. The low amylolytic activity in the pancreas may be particularly noticed during the first 4 weeks, at this time it attains $9 \cdot 10^{4}$ units, after which it increases rapidly until 8 weeks of age $\left(35 \cdot 10^{4}\right.$ units). Therefore there appears to be a phenomenon of adaptation of amylase to a diet that becomes increasingly rich in starch. Lipase activity also increases with age while the diet becomes poorer in lipids. This result confirms the numerous data obtained by Desnuelle et at. (I960-1965) who have never observed an adaptation of this enzyme to the composition of the diet. In addition, the activity of trypsin is low in relation to the activity of chymotrypsin, and the ratio $\frac{\text { chymotrypsin }}{\text { trypsin }}$ is constant, about $4: \mathrm{I}$, at each stage during measurement. This is the first time that this result and the almost parallel development of trypsin and amylase with age have been recorded.

With regard to the activities of intestinal glucosidases, the low activity in the duodenum 
should be remarked. There is an increase in total activity with age (as in the case of the pancreas), particularly of maltase and invertase, in the two posterior segments of the intestine. Thus, for example, the activity of maltase, very low at birth ( $\mathrm{I} \cdot \mathrm{IO}^{4}$ International Units) attains $15 \cdot \mathrm{IO}^{4} \mathrm{IU}$ at 3 weeks and $50 \cdot \mathrm{IO}^{4} \mathrm{IU}$ at the 8 th week in the jejunum. The total quantities of invertase show the same changes, but the activity at birth is null in all the segments studied; it attains $10^{3} \mathrm{IU}$ at $\mathrm{I}$ week and $\mathrm{IO} \cdot \mathrm{IO}^{3} \mathrm{IU}$ at 8 weeks in the jejunum and a si milar value in the ileum. This is a classic result and it allows the conclusion to be made that there is an adaptation similar to that observed for pancreatic amylase. On the other hand, with regard to the localization of the enzymes, our results differ from those of DAHLQUIST (I96I) who worked on only a small number of animals.

Lactase evolves in a particular manner i.e galactosidase activity is high at birth in the jejunum $\left(3 \cdot 10^{5} \mathrm{IU}\right)$, but there is a maximum activity at about 6 weeks $\left(\mathrm{I}_{5} \cdot \mathrm{IO} \mathrm{O}^{5} \mathrm{IU}\right)$, the activity is lower in the ileum ( 2 to $4 \cdot 10^{5} \mathrm{IU}$ ) and appreciably constant with age, while it is almos null in the duodenum. In general, the values obtained differ from the usual data, which have almost always been derived from measurements on the enzymatic activity of the intestinal mucus alone.

However, the results presented here allow the principal phenomena of the development of the piglet during the suckling period and at weaning to be specified. One can consider that this period is characterized not only anatomically by the increase in weight of 2 digestive organs, the pancreas and the intestine, but also by an increase in enzymatic activity.

\title{
CONTRÔLE DE L'ÉVOLUTION DE L'ÉQUIPEMENT ENZYMATIQUE DU PANCRÉAS EXOCRINE DU LAPIN DE LA NAISSANCE A 6 SEMAINES
}

\author{
T. CORRING, F. LEBAS et D. COURTOT \\ Station de Recherches sur l'Élevage des Porcs, \\ Centre national de Recherches zootechniques, I. N. R. A., \\ 78 - Jouy-en-Josas
}

Dans le but de vérifier l'hypothèse d'une adaptation du pancréas exocrine du lapereau sous la mère, aux variations de composition du régime alimentaire au moment du sevrage (LEBAS, Corring, Courtot, I97I) (1), 2 lots de 6o lapins ont été affectés aux régimes expérimentaux suivants :

I. Régime lacté maternel uniquement, de la naissance au $3^{\mathrm{e}}$ jour et sevrage brutal avec un aliment amylacé.

2. Régime lacté maternel uniquement, de la naissance au $20^{\mathrm{e}}$ jour et sevrage brutal avec le même aliment amylacé.

Le dosage des 4 principales enzymes digestives pancréatiques a été réalisé à 9 stades répartis entre 7 et 42 jours. Les activités lipasique, amylasique, trypsique et chymotrypsique ont été dosées sur des broyats de pancréas.

Quel que soit le régime expérimental, les activités enzymatiques présentent toutes une aug- 